\title{
REINFORCEMENT THE INDEPENDENT OF CULTURAL VILLAGE COMMUNITIES BY E-TOURISM IN KOTO SENTAJO
}

\author{
Yohannes Firzal $^{a *}$, Chelsy Yesicha ${ }^{a)}$, Andry Sulistiyani ${ }^{a)}$, \\ Safri $^{a)}$, Genny Gustina Sari ${ }^{a)}$ \\ a) University of Riau, Pekanbaru, Indonesia \\ ${ }^{*}$ Corresponding Author: yfirzal@eng.unri.ac.id
}

Article history: received 09 August 2020; revised 28 August 2020; accepted 14 September 2020

\begin{abstract}
This article is a research conducted in the cultural tourism village of Koto Sentajo. The research was initiated by creating a network with various related advice and assistance in improving the quality of local community skills through training and hands-on practice which aims to be able to help increase income for the village. Apart from the collection of Rumah Godang, this tourist village is also enriched with natural beauty such as protected forests, rice fields and rivers that have interesting potentials for the benefit of local residents. However, all the potential of this tourist village has not been well mapped as a tourist attraction and is supported by tourism promotion management. This then becomes an interesting object of research on how all the potentials of this tourist village can be mapped and helps strengthen community independence in managing existing tourism potential. This research puts forward the method of direct local community participation in data collection which is also supported by the method of interviews, observation and literature study. The research succeeded in carrying out a comprehensive mapping of tourism potential on a number of tourist objects, cultural attractions, culinary delights and local arts. In terms of strengthening the role, the community has begun to be able to receive live in tours through various involvement of tourism activities in their daily activities. This new phenomenon in the life of cultural village communities is an indication that the community can grow and develop in terms of tourism through inclusive behavior in accepting tourists and at the same time promoting local tourism potential towards e-tourism.
\end{abstract}

Keywords: mapping; independence; tourism; culture

\section{INTRODUCTION}

Koto Sentajo is the oldest village in Kenegerian Sentajo in Kuantan Singingi Regency, Riau. Koto Sentajo is estimated to have existed around the 11th century. The word Koto means a city marked by a mosque and surrounded by rivers. Meanwhile, the word Sentajo comes from the word Sheikh Tajo. The word Tajo itself has two meanings, namely unexpectedly meeting, and an expression of awe or awe. Although it is still debated and contested, Koto Sentajo is often assumed to have a close relationship with Minangkabau culture [1]. This is based on the analogy of the location of the village which is located in the KuantanIndragiri river. This river originates from Lake Singkarak in West Sumatra which is dominated by the Minangkabau tribe and empties into the Melaka Strait.

Another assumption explains that Koto Sentajo is a remnant of the civilization of the Kandis Kingdom which is centered on Bukit Bakar Lubuk Jambi which existed around the 1st century. As a result of the war, the Kandis kingdom then moved and turned into the Kuantan Kingdom which was ruled by three traditional leaders. Datuak Simambang is domiciled in Sentajo with the territory of Sentajo, Pangean, Baserah, Inuman and Pasikaian Cerenti with the title Datuak Mongguang. Then Datuak Pobo was domiciled in Kopah with the title Datuak Patih which had territories ranging from Sampurago, Lubuak Ambacang, Lubuak Jambi, Koto Tuo, and Sungai Pinang. Meanwhile, Datuak Bandaro Lelo
Budi is domiciled in Kari, with territories ranging from Kari, Teluk Kuantan, Suberakun, Simandolak to Sibuayo. Including Mount Toar, Teluk Wish and Lubuk Terentang represented to Datuak Bandaro.

Village leadership changed with the enactment of the Law on village administration in 1965 . Broadly speaking, this regulation regulates the structure of village government. As a result, the term village was replaced with the title village, and the village head did not have to be a tribal head. Further changes occurred in 1979 with the enactment of laws regulating uniformity and the position of villages. This provides an opportunity for the community to participate in the development and implementation of village administration. [2].

Local architecture and culture are valuable assets for tourist villages. [3] Koto Sentajo Village has 27 units of Rumah Godang as a symbol of the harmony of the four tribes, namely the Malay, Paliang, Caniago, and Patopang tribes. The existence of this traditional building feels integrated with the surrounding environment which is still enriched by the natural beauty around. The Koto Sentajo people still preserve their social customs. This can be seen clearly in the daily way of life, such as greeting older people and the manners of associating with local youth in various cultural events such as marriage, circumcision, engagement and holiday celebrations. The preservation of local cultural traditions can be found at Eid al-Fitr, especially during the celebration on the second day. Relatives from each tribe will 
gather to the village of Koto Sentajo on that day. A tradition like this has been going on for quite some time and is a moment that only happens once a year. In this context, they are called to continue to preserve this hereditary tradition.

Traditional local wisdom in the daily life of the Koto Sentajo people can become tourism potential. People's understanding of the preservation of traditions until now will have an ideal correlation to support the preservation and development of a live-in nuanced tourist attraction. Of course, efforts to preserve this tradition need to be supported through the empowerment of the Koto Sentajo community. Empowerment is a process of developing, independent, selfempowering, strengthening the bargaining position of the lower classes of society against the pressing forces in all fields and sectors of life [4]. In this case, the community independently is expected to be the driving force for the operation and maintenance of facilities [5].

According to some researchers, cultural heritage can help preserve the cultural heritage of a destination. However, this also depends on various factors, including those related to government policies and guidelines [6]. In this context, Koto Sentajo has been designated as a tourist area and a tourist attraction through the decision letter of the Regent of Kuantan Singingi Regency in 2017. This clarity of legal standing plays a role as a strong foundation and the main key to the success of realizing the potential of a tourism village in the context of developing Koto Sentajo as a destination tourism village in the future (Kpts Regent Decree 257/11/2017). Tourism village activities are generally focused on developing target areas that have a relationship between functions and influences with elements of tourist attraction in the form of natural diversity, culture and manmade products, as well as tourism business facilities and creative industries.

Mapping the potential for tourism objects in cultural villages is correlated in reflecting the patterns of the use of natural resources around them, including in improving the local household economy. In this study, the researcher briefed this potential by utilizing information and communication technology. Naturally, this can support the interactivity between tourism managers and consumers, known as e-tourism. In several areas of tourism development by utilizing e-tourism, it is proven to have a big impact. The communication revolution that accompanies the advancement of communication technology today also guides the tourism industry to be aligned in utilizing promotional strategies through digital means.

The research team mapped the potential for tourist objects as well as strengthening the independence of the Koto Sentajo community in managing this tourism potential in order to prepare for the promotion of e-tourism. The etourism method is needed by potential tourists to access destination destination information, but it is limited in number. The existence of a WAP-based support system makes it easy to provide information directly according to admin and user needs, makes it easier to manage hotel reservations, update hotel data, and direct bookings so that users can interact directly with tourism service providers. [7].

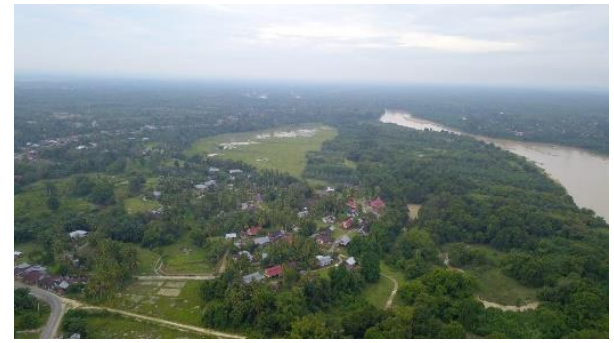

Figure 1. The Aerial view of Koto Sentajo

\section{RESEARCH METHODS}

This research applies participatory methods to local communities, officials and village leaders through engagement and dialogue. This aims to find out more deeply about the procedures for daily activities, history and the perspective of the local community in terms of preserving customs and traditions that are the potential of the Koto Sentajo tourist village. Researchers also involved 10 students to explore and record the life of the community in Koto Sentajo. In collecting field data, researchers also used indepth interviews with various stakeholders, such as the head of State Sentajo Affairs, Village Heads, Penghulu Bonsu, historical figures and the general public who know about the potential of tourism villages. Direct observation in the field and literature review collection methods are research methods that are also carried out in this study.

\section{RESULTS AND DISCUSSION}

This research was conducted for three consecutive years. In the early stages of the first year, success was achieved in building a network that aims to build awareness and cooperation with related parties, especially the community to realize the Koto Sentajo tourist village [8] Meanwhile, the second tofu research focuses on local community skills activities to increase village income through training and tourism package management practices, including providing homestays at Rumah Godang, training tour guides and providing typical culinary delights for tourists. The increase in the capacity of the local community in terms of tourism has begun to become apparent and this is the result of various forms of training that are direct and needed. However, although managerial can show readiness, there is still a need for broad cooperation and supervision related to instilling awareness and changing people's habits to live with tourists, especially with orientation to health and hygiene [5]. This needs to be adjusted to the current pandemic conditions as well as outside managerial in order to show the wider public the potential and readiness of the community to receive tourists.

\section{Potential Tourism Objects of Koto Sentajo Village}

The development of geoculture treck tourism potential is also a local branding. Because the realm of tourism is closely related to the development of economic 
enterprises [9]. However, the economic impact of tourist arrivals has not been felt evenly and thoroughly on the community. The importance of community openness in accepting the arrival of foreigners into the customary environment deserves great attention. The strictness of traditions and customs seems to make the Koto Sentajo people seem to shut themselves off to outsiders. Therefore research in the 3rd year emphasizes community involvement in arranging manageable tour packages to be offered to tourists. Researchers have mapped several tourist objects together with local communities.

The Old Mosque is known as the oldest building in Koto Sentajo. This mosque is thought to have been founded in 1735 and is currently named the Old Mosque of Raudathul Jannah. The architectural characteristics of the mosque are supported by 17 wooden poles that reflect traditional symbols as representatives of the four tribal leaders, namely Penghulu, Tangganai, Anak Menti, and Dubalang (Figure 2).

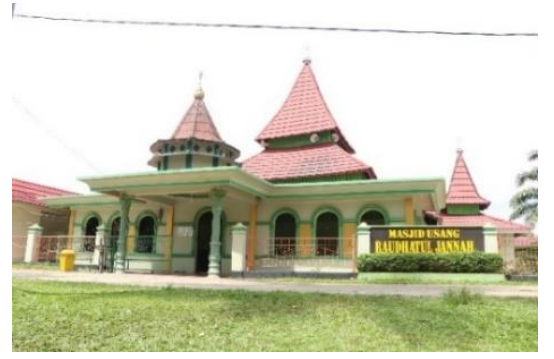

Figure 2. The Mesjid Usang at Koto Sentajo

Another important tourist potential is the $400 \mathrm{Ha}$ protected forest. This forest was originally known as Sentajo statewide ban which means customary forest (Figure 3). As a national forest, there are customary rules in the utilization of the wealth found in the forest such as forest honey, Rattan (callamus sp), Bamboo (saccharum sp). Fruit Kumpalan boning (Nephelium sp), Kabau (adhinantera sp), Barangan (Castaopsis sumatrana), Tampui (Baccaurea macrocarpa), Kedondong forest (Spondias pinnata), Paro charcoal (Nephelium sp), Cempedak forest (Artocarpus rigidus), Pudung tunjuak (Nephelium sp), marsawa, kulim, and aloes. Not only the richness of flora, in this protected forest you can still find other protected animals such as crows (Corvus corax), hornbills (Buceros sp), Turtledoves (Geopelia striata sp), Murai batu (Copsychus sp), monkeys (Macaca fascicularis), hornbills, bear and tiger.

There are several customary rules that regulate protected forests in order to protect the balance of relations between forests and indigenous peoples. The rule of entering the forest with the permission of the chiefs was robbed. This is based on the assumption that the forest is a sacred place since the time of our ancestors. Then the rules in utilizing some of the forests that must be approved by the customary leaders, especially in some functions that can bring benefits to the indigenous people Other rules related to the use of forest products. This is mainly related to the acquisition of wood intended for customary purposes such as materials for making paths, repair of custom houses, houses of worship, village bridges and village halls.

Timber extraction is closely monitored not only by customary leaders, but also from elements of local government. In terms of enforcement of sanctions, customary law to address violations of the rules for using protected forests [10].

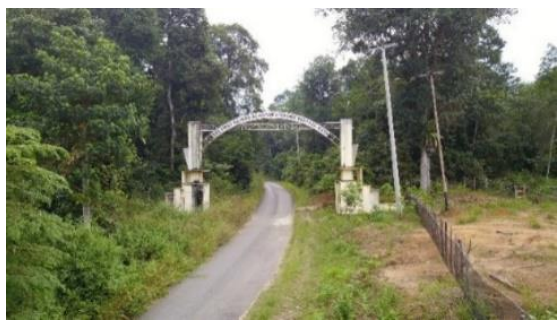

Figure 3. The gate of the Rimbo Larangan at Sentajo

The village which is located on the edge of the river will provide its own characteristics like the local community in utilizing the existence of the river. From ancient times until now, rivers are still an important transportation channel in the movement of people [11]. The river has its head in the Singkarak lake in West Sumatra. The upstream area of the river is known as Batang Ombilin. The next section is called Batang Sinamar, Batang Kuantan and the estuary is known as Batang Indragiri which borders the Melaka Strait. Koto Sentajo itself is located in the Batang Kuantan area which is used for the daily interests of the community. In line with the decreasing quality of river water, the current use of rivers is limited only as a transportation channel and for fishing.

Kuantan Putui is part of the Batang Kuantan river which is in direct contact with the Koto Sentajo area (Figure 4). This naming is related to its position which stretches parallel to the unconnected nanum river. With these conditions, local people also call Kuantan Putui a lake. Although it is permissible, but utilizing the results of the lake's existence is strictly regulated so that there is no overexploitation [10].

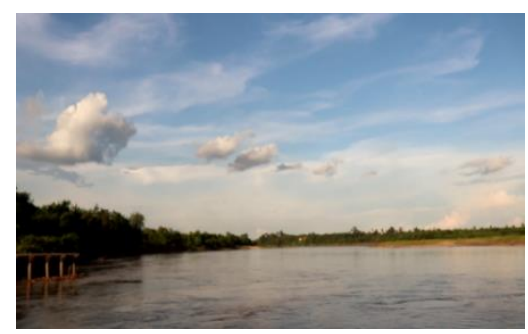

Figure 4. Kuantan Putui in Kuantan Batang Area

\section{Community Traditions to Cultural Tourism Attractions}

The tradition of raising buffalo together or also known as free buffalo is an activity that has been formed in Koto Sentajo. Supported by extensive grasslands, buffalo free-range activities have become part of the daily life of the local community. A group of buffaloes are shepherded alternately every day by people who are appointed and agreed upon by the owners, and are also housed in the same 
location in Koto Sentajo. Furthermore, the buffalo is a symbol of the prosperity of its owner and is also related to the position of the social strata of society. Thus, buffalo freeze has become a hereditary tradition which has been maintained to this day (Figure 5).

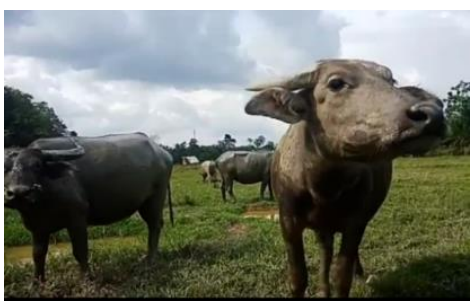

Figure 5. Angon Kerbau as a cultural tradition at Koto Sentajo

The traditional topping game has become part of the daily life of the Koto Sentajo people. Gasing can be defined as a traditional wooden game played by rotating it with the help of a rope wrapped around the top. At this time, the game of top is more popularly played by teenagers, but at certain times it can become part of local cultural celebration events (Figure 6 ). Usually the top game is held in an open field which is followed by several players. The winner of the game is determined by the length of time that the top spinning or top can survive when pitted against one another.

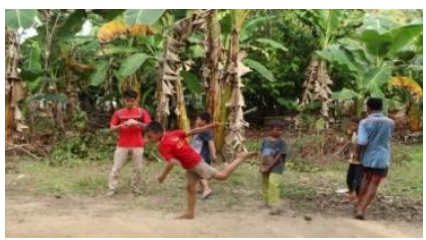

Figure 6. Gasing Traditional Games as Part of Daily Actifity

Traditional martial arts in Koto Sentajo is taught to boys from youth to adolescence. Usually this traditional martial arts is taught at night during the fasting month of Ramadan, precisely at the time after the implementation of tarawih and witr prayers. This learning aims not only to be used as a martial art, but also related to practicing Islamic teachings. So that the values of politeness, honesty, obedience, tolerance and mutual respect are important bases in practicing traditional silat which is also known as Silat Pandekar Batuah. Traditional martial arts every year is shown openly to the audience on the event of the second day of Eid al-Fitr celebration every year (Figure 7).

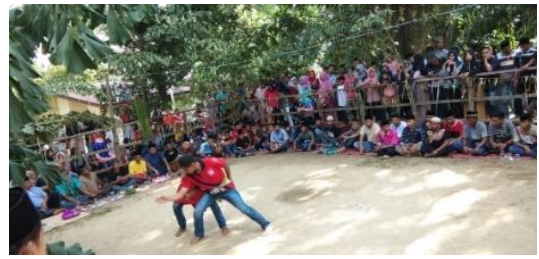

Figure 7. Traditional Silat during the Hari Raya Celebration
The lane is a traditional boat that has become an icon and event. The word lane is a local native language which means a large boat made of one tree trunk. The creation of one line unit is also a requirement with traditions and cultural requirements that are closely related to the daily life of the Koto Sentajo community. Starting from the process of taking wood, it should not be done carelessly, the craftsman who will make the path must go to the forest and ascertain whether the wood is suitable for the path or not. The traditional handler's role also enters the forest to ensure that the logs to be felled are used as pathways. The handler will communicate with the guardian of the tree and ask to be allowed to cut, followed by burning incense, slaughtering chickens and other conditions.

Initially, routes were used for means of transportation and for transporting daily goods such as rice. The design and decoration of the paths use distinctive characters that indicate where the path came from. Likewise with the Koto Sentajo route which uses the motif of the godang house carvings. However at this point in time, the track is mostly used for competitions and other special events. When the track is not used for competitions, events or training, the lane will be kept in a lane cage located on the riverbank and cared for collectively by the local community (Figure 8). The placement of the cage for this route is due to consideration regarding the ease of raising and lowering it into the river when needed.

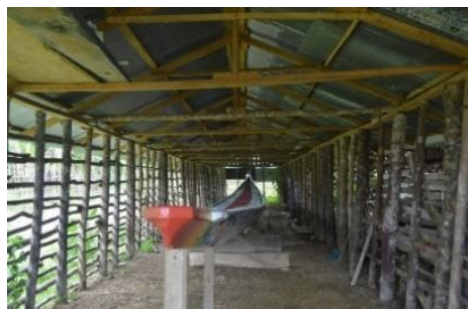

Figure 8. Line enclosures on Komang Island and Koto Sentajo

The level of life can be enjoyed by an individual or family based on their income or other sources of income [12]. Typical culinary delights that can be enjoyed and become the souvenirs of Koto Sentajo such as carambial chilli which is a place mixed with grated coconut, processed until it has a dry texture and can last a long time (Figure 9).

Another typical culinary is known as Rondang Paku which is made from ferns as the main ingredient. This is because this type of vegetable grows a lot in Koto Sentajo. There is Puluik Tungkuih, this food is usually served with black sticky rice tapai during traditional events or other important events. Besides old culinary delights, Koto Sentajo also seeks to develop the latest culinary wealth. One of the latest culinary innovations is Gaharu Tea, processed gaharu leaves that are dried from local protected forest products. Until now, Gaharu tea from Koto Sentajo is still a culinary delicacy that has recently been developed by the community and has the opportunity to be cultivated. 


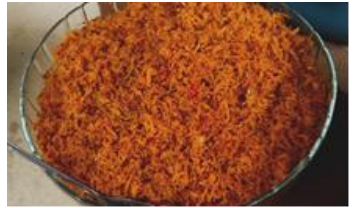

Figure 9. Carambial Sauce

3. Efforts to Strengthen Community Independence in Live In Tourism

Previously, the Team had seen the readiness and openness of the villagers in entertaining and receiving direction regarding tourism activities. In this context, the community has begun to show its readiness as an ecocultural based tourism village. Eco-culture-based tourism is a concept for tourist villages that is able to combine ecological aspects of environmental ecosystems and community culture in arranging settlements towards livable and sustainable livelihoods. Thus, space in the village of Koto Sentajo will increasingly be explored in accordance with the natural conditions and local culture [13]. This shows that the Koto Sentajo community is towards independence in creating an independent and reliable tourism village.

Some of the tourism village traditions based on ecoculture are starting to be well organized, such as seeding activities (Figure 10). Rice seed sowing activities are generally carried out by a group of mothers. Before sowing, first the soil is perforated using wood known as menungal. Tourists can participate directly in the process of seeding this rice seed.

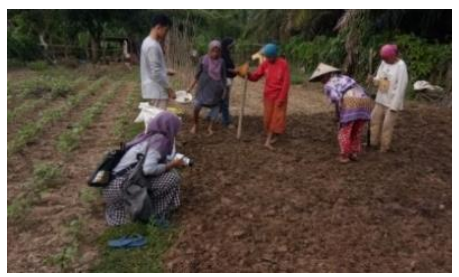

Figure 10. Harvesting the seeds

Another unique eco-cultural tourism activity is known as tanning fish (Figure 11). Tourists can participate in the activity of tanning fish which is usually done by women when fishing in the Batang Kuantan river. Posok, a traditional tool used by the community to this day. This tradition is still maintained as one of the livelihoods both for sale and to fulfill daily food needs.

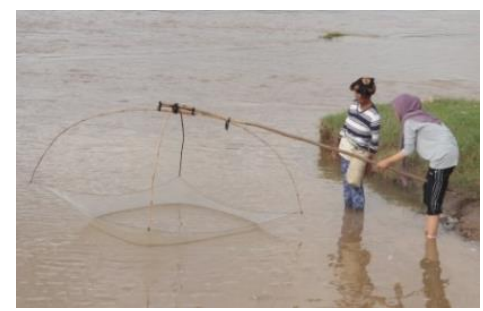

Figure 11. Cheating Activities with Traditional Equipment
Exploring the panorama of the protected forest is also part of the eco-cultural tourism activities that are starting to develop in Koto Sentajo (Figure 12). Tourists can explore the protected forest to be able to enjoy the view of sports and even interact when meeting with fauna and flora.

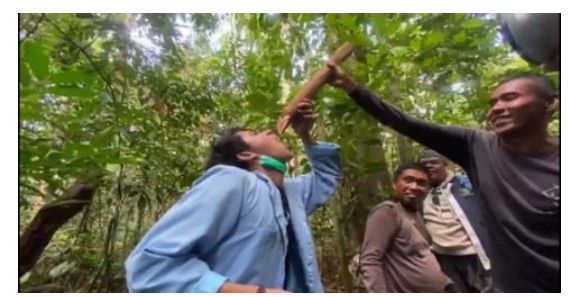

Figure 12. Entering the Koto Sentajo protected forest

Apart from exploring nature tourism, cooking and eating special culinary activities can also be an attraction for eco-cultural tourism at Koto Sntajo (Figure 13). Together with mothers, tourists can get involved in cooking specialties while singing local songs so that they present a sense of kinship that is required with cultural nuances. Through the enrichment of typical songs in tourism activities, it will further strengthen the concept of authenticity of local culture [14].

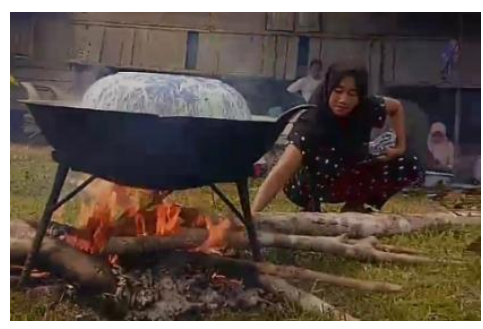

Figure 13. Cooking typical culinary Koto Sentajo

Efforts to strengthen the independence of the Koto Sentajo village community in realizing a tourist village are a form of success for the research team and the community in opening greater promotional opportunities in receiving tourists. Residents do not hesitate to invite and teach what they do in their daily lives, which is part of local wisdom. This local wisdom reflects local identity / personality in actualizing potential [15].

Information delivery in the form of tourist villages can be realized in the form of a map of the formulation of plans obtained on the basis of data compilation studies and regional data analysis. [16] Previously, village tour packages were not initially available either independently or from the local government. In this context, the research team offered the concept of an independent package through the Pokdarwis Desa Koto Sentajo. Tourism village empowerment programs like this aim to make local communities able to develop local cultural wisdom values so that they have a tourism "selling value", without destroying the consistency and strength of the meaning of the value itself. [17].

Apart from tourism packages, promotion in the form of e-tourism can also play an important role in supporting 
the independence of tourism villages. E-tourism promotion activities can be started with information on tourism objects on the internet page / website. Through various assistance activities, later the management of the Koto Sentajo etourism page will be fully managed by Pokdarwis. Thus, Pokdarwis will be more efficient and effective in offering the potential of Koto Sentajo village such as the godang house that can be converted into a homestay when tourists visit.

The use of the e-tourism approach will provide various facilities, not only information. Various features and facilities are available for ease of processing for its users, such as assisting in making various interactive map animations from the Google Maps API on the web to make it easier to find locations so that with adequate and varied facilities more optimal results can be obtained [18].

The development of an independent tourism village requires the support and involvement of all stakeholders in the tourism sector. The community is part of an important element as a stakeholder together with the government and business / private sector to work together to implement and support tourism development. Therefore, tourism development must pay attention to the position, potential and role of the community as either the subject or actor or beneficiary of development, because community support also determines the long-term success of tourism development.

Likewise with the development of the Koto Sentajo tourist village. To support and develop tourism in Koto Sentajo Village, it is hoped that Pokdarwis can become a motor for managerial and operational e-tourism activities by mastering and implementing applications on mobile devices [18]. This is also conveyed by [19] that internet users state that the elements of responsiveness and interactivity are things that need to be prioritized. Thus the factor of internet service costs and internet expertise is no longer an obstacle to accessing tourism sites.

\section{CONCLUSION}

Through research and mentoring activities for three consecutive years, the research team concluded that various forms of comprehensive, direct information are needed by the Koto Sentajo community. This is mainly related to promotional activities in accordance with the mapping of points of visit and information for tourists. The people of Koto Sentajo are considered to have been able to be good hosts in conveying information about the uniqueness of objects, attractions, culinary delights and their distinctive arts by acting like a tour guide and welcoming tourists. This is supported by the growth of openness that they show in their interactions with tourists / newcomers. However, various training activities and direct assistance for the community in web management, promotion and service to tourists still need to be improved, especially in relation to the current pandemic situation. Modification of attractions, visits can be included with supporting facilities and infrastructure. Tour packages need to be readjusted by aligning with health protocols or supplemented with the Koto Sentajo Village tourism website.

\section{REFERENCES}

[1] T. Kato, „The Localization of Kuantan in Indonesia From Minangkabau Frontier to a Riau Administrative District", Bijdr. tot Taal-, Land-en Volkenkd., roč. 153, č. 4, s. 737-763, 1997.

[2] T. Kato, ,Adat Communities and the Village Law of 1979 in Indonesia", Southeast Asia Progr., roč. 47, č. 47, s. 89-114, 1989, [Online]. Dostupné z: http://www.jstor.org/stable/3351077 .

[3] W. Hidayat, „Transformasi Bentuk Arsitektur Rumah Godang Pada Perancangan Museum Jalur Kuantan Singingi Gushendri, Wahyu Hidayat dan Muhammad Rijal", Jom Fteknik, roč. 2, č. 1, s. 1-15, 2015.

[4] Cholisin, „Pemberdayaan Masyarakat (Disampaikan Pada Gladi Manajemen Pemerintahan Desa Bagi Kepala Bagian/Kepala Urusan Hasil Pengisian Tahun 2011 Di Lingkungan Kabupaten Sleman, 19-20 Desember 2011)", s. 1920, 2011, [Online]. Dostupné z: http://staff.uny.ac.id/sites/default/files/tmp/Pemberda yaan Masyarakat.pdf.

[5] C. Yesicha, A. Sulistyani, Y. Firza, a G. G. Sari, „2020 Penyuluhan Hidup Sehat dan Bersih Warga Desa Koto Sentajo sebagai Destinasi Wisata Budaya di Riau", s. 20-26.

[6] Y. Li, „Heritage Tourism: The Contradictions between Conservation and Change", Tour. Hosp. Res., roč. 4, č. 3, s. 247-261, 2003, doi: $10.1177 / 146735840300400305$.

[7] H. Himawan, „E-Tourism: Antara Konsep Dan Implementasi Dalam Mendukung Industri Pariwisata Indonesia", Semin. Nas. Inform., roč. 1, č. 5, s. 214-221, 2015, [Online]. Dostupné z: http://jurnal.upnyk.ac.id/index.php/semnasif/article/v iew/935.

[8] F. Zulpikar, A. Gandhy, W. El Kiyat, F. Zulpikar, A. Gandhy, a W. El Kiyat, „Improving Food Access For Marginal Urban Community Through Vertical And Organic Farming Training", roč. 4, č. 2, s. 115$124,2020$.

[9] A. R. Nugraha, S. Perbawasari, a F. Zubair, ,,Model Komunikasi Pariwisata Yang Berbasiskan Kearifan Lokal", J. Messenger, roč. 9, č. 2, s. 231, 2017, doi: 10.26623/themessenger.v9i2.468.

[10] M. Wabula, D. I. Kabupaten, T. Mustari, S. Manaf, L. Ode, a A. Munafi, „Laut Berbasis Kearifan Lokal Pada", s. 53-63.

[11] S. Yandri, S. R. Sari, a A. B. Sardjono, „Space Function and Shape of Balai Adat in Koto Sentajo Traditional Village", J. Archit. Des. Urban., roč. 1, č. 2, s. 9, 2019, doi: 10.14710/jadu.v1i2.4430. 
[12] N. M. Hartati, „Pemanfaatan Objek Wisata Ceking Terrace Terhadap Pendappatan Masyarakat Di Kawasan Ceking Terrace", roč. 4, s. 1-12, 2014.

[13] A. Asmuliany, A. A. Amalia, A. Asmuliany, a A. A. Amalia, „Ecoculture Based Of Fisherman Settlement Development In Barombong Village Makassar", roč. 4, č. 2, s. 186-194, 2020.

[14] W. Sriwulan, „Studi Analisis: Konsep Musikal Randai Kuantan Di Teluk Kuantan-Riau Melalui Teori Semiologi Musik", roč. 2, č. 2, s. 259-270, 2019.

[15] I. Bakti, S. Sumartias, T. Damayanti, a A. R. Nugraha, „Pengembangan Model Komunikasi Pariwisata Berbasis Kearifan Lokal di Kawasan Geopark Pangandaran", J. Kaji. Komun., roč. 6, č. 2, s. 217, 2018, doi: 10.24198/jkk.v6i2.18459.

[16] Ririn Wesliner, „No 主钼的健康感を中心とした 在宅高齢者における健康関連指標に関する共分 散構造分析Title", roč. 2012, 2013.

[17] A. Yuningsih, „Konsistensi Kearifan Lokal di Desa Wisata "Sunda Buhun ”", Bunga Rampai Komun. Indones., s. 51-65, 2012.

[18] I. W. W. Gautama, I. K. Gede, D. Putra, a I. M. Sukarsa, „Aplikasi Pemetaan Objek Wisata Pantai Bali Selatan Berbasis Android", J. Ilm. Merpati (Menara Penelit. Akad. Teknol. Informasi), roč. 4, č. 1, s. 43-51, 2016.

[19] M. R. Shihab a A. Murtadho, „Analisis Situs ETourism Indonesia: Studi Terhadap Persebaran Geografis, Pengklasifikasian Situs Serta Pemanfaatan Fungsi Dan Fitur", J. Sist. Inf., roč. 7, č. 1, s. 13, 2012, doi: 10.21609/jsi.v7i1.290. 